\title{
Postoperative hemorrhage complications following the Whipple procedure
}

\author{
Osman Nuri Dilek ${ }^{1}$, Oğuzhan Özşay² ${ }^{2}$ Turan Acar ${ }^{2}$, Emine Özlem Gür ${ }^{1}$, Salih Can Çelik² ${ }^{2}$ Fevzi Cengiz ${ }^{2}$, Nejat Cin², Mehmet Haciyanlı \\ 1 Department of General Surgery, Izmir Katip Celebi University School of Medicine, Izmir, Turkey \\ ${ }^{2}$ Clinic of General Surgery, Ataturk Training and Research Hospital, Izmir, Turkey
}

\section{ABSTRACT}

Objective: Although the Whipple operation is an essential surgical technique, its high morbidity (30\% to $60 \%$ ) and mortality (5\%) are problems to be addressed. The incidence of postoperative hemorrhage has been reported between $5 \%$ and $16 \%$ in the literature. In this study, the data and results regarding postoperative hemorrhage complications from our clinic were evaluated.

Material and Methods: The files of 185 patients who had undergone Whipple operation in our hospital in the last five years were evaluated retrospectively, and the causes of hemorrhage were attempted to be determined.

Results: It was found that 6 out of the 13 (7\%) patients who had hemorrhage died. In six of there 13 cases, hemorrhage occurred due to fistulas from the portal vein, gastroduodenal artery, and pancreatic arteries at variable periods. Two cases were found to have developed disseminated intravascular coagulation as a result of sepsis. Early intervention was performed in two cases who bled from the meso veins and in one case who bled from the portal vein. Laparotomy and hemostasis were performed in a patient who bled from the gastric anastomosis line. In a patient who had been taking low molecular weight heparin, bleeding from the drains and nasogastric tube stopped following the cessation of the drug.

Conclusion: Preventive procedures such as connection of the vascular structures, use of vascular sealants, omental patching during surgery, and reducing the risk of complications by using somatostatin analogs were performed to prevent hemorrhages after Whipple operations. In addition to standard methods, angiography and embolization have emerged as effective methods in the diagnosis and treatment of hemorrhages. Furthermore, determination and elimination of independent risk factors, such as jaundice, affecting fistula formation and bleeding in the perioperative period, is important for prevention.

Keywords: Complication, hemorrhage, pancreas, treatment, whipple operation

Cite this article as: Dilek ON, Özşay O, Acar T, Gür EÖ, Çelik SC, Cengiz F, et al. Postoperative hemorrhage complications following the whipple procedure. Turk J Surg 2019; 35 (2) $136-141$

\section{Corresponding Author}

Osman Nuri Dilek

E-mail: osmannuridilek@gmail.com

Received: 13.11.2016

Accepted: 20.04.2017

Available Online Date: 03.01.2018

OC Copyright 2019 by Turkish Surgical Society Available online at www.turkjsurg.com

DOI: $10.5578 /$ turkjsurg. 3758

\section{INTRODUCTION}

Although the Whipple operation is an essential surgical technique for periampullary tumors, its high morbidity (30\% to 60\%) and mortality (5\%) rates are problems to be addressed (1-3). Pancreatic fistulas (2\% to 62\%) are among the most common complications after Whipple procedure $(1,4)$. The incidence of postoperative hemorrhage has been reported as $5 \%$ to $20.2 \%$ in the literature and mortality due to hemorrhage as $15 \%$ to $58 \%(1,5-7)$. Hemorrhages may arise from the suture lines in the early period, and this study aimed to evaluate the data and results regarding postoperative hemorrhage problems in cases who developed infections and fistula in the days following surgery in our clinic.

\section{MATERIAL and METHODS}

The files of 185 patients who had undergone Whipple operation in our hospital in the last five years (2011 to 2015) were evaluated retrospectively, and the causes of hemorrhage were attempted to be identified. As a routine procedure, all patients signed consent forms containing information about the procedures and complications. Cases who had hemorrhoids, anal fissure, and etc. were excluded from the study. Our patients were classified as A, B, or C on the basis of postoperative pancreatic hemorrhage (PPH) consensus classification by the International Study Group of Pancreatic Surgery in 2007 as onset of hemorrhage (early or late), localization (extraluminal or intraluminal), and intensity (mild or severe) (Table 1) (5,6). Hemorrhages seen in the first 24 hours were identified as early hemorrhage. Leaking hemorrhages originating from drains or nasogastric tubes in the early postoperative period, those that stopped spontaneously, and those that did not alter the patient's hemodynamic stability were not taken into consideration. Mild hemorrhage 
Table 1. Patient characteristics

\begin{tabular}{|c|c|c|c|c|c|c|c|c|}
\hline Patient no & Age/Sex & $\begin{array}{l}\text { Indication for } \\
\text { Whipple /PD }\end{array}$ & Etiology & Bleeding site & $\begin{array}{l}\text { ISPG } \\
\text { group }\end{array}$ & $\begin{array}{l}\text { Onset of } \\
\text { bleeding }\end{array}$ & Procedure & Outcome \\
\hline 1. & $58 / \mathrm{M}$ & Bile duct tumor & PO Arrest-CPR-Sepsis & $\mathrm{DIC}$ & C & Day 5 & ICU & Died \\
\hline 2. & $65 / M$ & $\begin{array}{l}\text { Pancreatic } \\
\text { carcinoma }\end{array}$ & PJ Haematoma & Pancreatic artery? & B & Day 4 & Primary suture & Died \\
\hline 3. & $66 / M$ & $\begin{array}{l}\text { Pancreatic } \\
\text { carcinoma }\end{array}$ & Fistula & GDA & B & Day 35 & $\begin{array}{c}\text { Laparotomy + Primary } \\
\text { suture + Angiography + } \\
\text { Embolization }\end{array}$ & Survived \\
\hline 4. & $60 / M$ & $\begin{array}{l}\text { Ampullary } \\
\text { cancer }\end{array}$ & LMW Heparin & $\begin{array}{c}\text { Drain }+ \\
\text { Nasogastric sond }\end{array}$ & A & Day 14 & Stop LMW Heparin & Survived \\
\hline 5. & $69 / M$ & $\begin{array}{l}\text { Ampullary } \\
\text { cancer }\end{array}$ & $\begin{array}{l}\text { Pancreatic fistula, } \\
\text { sepsis }\end{array}$ & $\mathrm{DIC}$ & $C$ & Day 11 & ICU & Died \\
\hline 6. & $42 / F$ & $\begin{array}{l}\text { Pancreatic } \\
\text { carcinoma }\end{array}$ & Inadvertent surgery? & GJ Anastomosis & A & Day 1 & $\begin{array}{l}\text { Laparotomy + Gastrotomy } \\
+ \text { Primary suture }\end{array}$ & Died \\
\hline 7. & $65 / F$ & $\begin{array}{l}\text { Ampullary } \\
\text { cancer }\end{array}$ & Pancreatic fistula & Portal vein & & Day 8 & $\begin{array}{c}\text { Laparotomy + Primary } \\
\text { suture }\end{array}$ & Survived \\
\hline 8. & $74 / \mathrm{M}$ & $\begin{array}{l}\text { Pancreatic } \\
\text { carcinoma }\end{array}$ & Pancreatic fistula & Portal vein & $C$ & Day 27 & $\begin{array}{l}\text { Angiography + Laparo- } \\
\text { tomy + Primary suture }\end{array}$ & Died \\
\hline 9. & $67 / F$ & $\begin{array}{l}\text { Pancreatic } \\
\text { carcinoma }\end{array}$ & $\begin{array}{l}\text { Pancreatic fistula, PJ } \\
\text { leakage + GJ leakage }\end{array}$ & $\begin{array}{l}\text { Traumatic Portal } \\
\text { vein laceration? }\end{array}$ & C & Day 15 & $\begin{array}{c}\text { Laparotomy + Primary } \\
\text { suture }\end{array}$ & Died \\
\hline 10. & $65 / M$ & $\begin{array}{l}\text { Bile duct } \\
\text { tumor }\end{array}$ & Pancreatic Fistula & GDA & B & Day 7 & $\begin{array}{l}\text { Angiography + Laparo- } \\
\text { tomy + Primary suture }\end{array}$ & Survived \\
\hline 11. & $58 / M$ & $\begin{array}{l}\text { Pancreatic } \\
\text { carcinoma }\end{array}$ & Inadvertent surgery? & $\begin{array}{l}\text { Mesenteric vein } \\
\text { branches }\end{array}$ & B & Day 2 & $\begin{array}{l}\text { Laparotomy + Primary } \\
\text { suture }\end{array}$ & Survived \\
\hline 12. & $67 / M$ & $\begin{array}{l}\text { Ampullary } \\
\text { cancer }\end{array}$ & Pancreatic fistula & Mesenteric vein & C & Day 7 & $\begin{array}{l}\text { Laparotomy + Primary } \\
\text { suture }\end{array}$ & Died \\
\hline 13. & $45 / M$ & $\begin{array}{l}\text { Pancreatic } \\
\text { carcinoma }\end{array}$ & Inadvertent surgery? & $\begin{array}{l}\text { Mesenteric artery } \\
\text { and vein branches }\end{array}$ & B & Day 1 & $\begin{array}{c}\text { Laparotomy + Primary } \\
\text { suture }\end{array}$ & Survived \\
\hline
\end{tabular}

ISPG: International Study Group of Pancreatectomy; GDA: Gastroduodenal artery; PJ: Pancreaticojejunostomy; GJ: Gastrojejunostomy; PO: Postoperative;

DIC: Disseminated intravascular coagulation; ICU: Intensive care unit; PD: Pancreaticoduodenectomy.

was identified as the condition where the patient was hemodynamically stabilized or where no need for any interventional or surgical procedures was identified during the follow-up of the patient. Severe hemorrhage was identified as hemorrhage with a high flow rate, originating from the drains or lumens, which altered the hemodynamic stability of the patient. Deaths seen within the postoperative 30 days were accepted as postoperative death. In our hospital, low molecular weight heparin $(L M W H)$ is routinely administered 12 hours after surgery and is stopped if any hemorrhage is suspected. Angiography and embolization can be performed in daytime cases.

\section{RESULTS}

A total of 185 pancreticoduodenectomy, including 165 classical Whipple procedures and 20 pylorus-preserving pancreatoduodenectomy, were performed in our hospital in the last five years (2011 to 2015) due to tumors of the periampullary region. Three of the patients were females, and 10 were males. Mean age was 61.6 years (range, 42 to 72 ).
It was found in 13 (7\%) of the patients who had undergone whipple operations that, a procedure was performed due to hemorrhage. Among the patients who had follow-ups due to hemorrhage, 9 (77\%) underwent surgeries and 6 (46\%) died in the early period (Table 1). In our series, pancreatic fistula was detected in 46 (24.8\%) patients, and 6 (13\%) of these patients had complications of hemorrhage due to fistulas. It was also found that endoscopic retrograde cholangiopancreaticography (ERCP) was performed diagnostically in nine patients, a stent was placed to lower billirubin levels in six patients, and a drain was placed with percutaneous transhepatic cholangiography in two patients.

In seven patients in our series, there was a combination of wide duct (4 to $7 \mathrm{~mm}$ ) and soft pancreatic texture; the presence of fistula was detected in three of these patients as the cause of hemorrhage. In three of our cases, soft pancreatic texture and the presence of a $2 \mathrm{~mm}$ duct were determined. In three of our cases, normal pancreatic tissue was observed with duct widths 
ranging from 2 to $5 \mathrm{~mm}$ (Table 1). Among our patients with hemorrhage, three of the five patients whose billirubin levels were high (direct bilirubin, range: 10.6 to $21.6 \mathrm{mg} / \mathrm{dL}$ ) died as a result of hemorrhage complications. Another result we found in our patients was that serum protein levels were normal in three patients and below normal in the remaining. Platelet count was higher than normal in five of our patients and was normal in the remaining. In cases who did not develop fistulas, C-reactive protein (CRP) levels were within normal limits in the preoperative period, increased in the postoperative early period, and decreased progressively. In all cases that developed fistula and anastomotic leakage, CRP levels continued to increase until clinical recovery was obtained. In general, it was found that in our patients who developed fistulas and had high CRP levels, blood calcium levels decreased and remained below normal.

Of our two cases who developed hemorrhage in the early postoperative period, one underwent surgery due to hemorrhage from the gastric anastomosis (nasogastric tube) and the other underwent surgery due to hemorrhage from the branches of the mesenteric vein (drain), both of whom discharged with complete healing. Six of our patients were found to have bled from the portal vein (three cases), gastroduodenal artery (two cases), meso veins, and pancreatic artery (one case) due to fistulas at variable periods. Hemorrhage from the portal vein after fistula was seen on the postoperative $8^{\text {th }}, 15^{\text {th }}$, and $27^{\text {th }}$ days, and two of these patients died after surgery (Table 1). In one of the cases that was on follow-up due to fistula and bleeding from the nasogastric tube, anastomotic leakage was detected by endoscopy. The patient was taken into surgery on the postoperative $15^{\text {th }}$ day; however, the patient died from hemorrhage found to have originated from erosion of the portal vein. In another patient who had blood coming out of the drain on the postoperative $7^{\text {th }}$ day, hepaticojejunostomy and pancreaticojejunostomy were found to be opened, and hemorrhage from the pancreatic artery and branches of the mesenteric vein were seen. In two cases, laparotomy was performed on the $2^{\text {nd }}$ and $4^{\text {th }}$ days due to bleeding from the drains; hemorrhages arising from the pancreatic artery and branches of the portal vein were repaired.

Two cases were found to have developed disseminated intravascular coagulation (DIC), and these patients died as a result of sepsis. In a patient who had been taking LMWH, bleeding from the drains and nasogastric tube stopped following the cessation of the drug.

\section{DISCUSSION}

Hemorrhage after Whipple surgery is a rare but serious complication that increases mortality. In the early period, hemorrhage may develop from technical problems, bleeding/clotting disorders, and factors related to the patient; however, in the latter periods, hemorrhage emerges as a serious problem during the course of fistula and anastomosis-related problems $(1,2)$. Hem- orrhage incidence in the postoperative period reported in the literature (5\% to $16 \%$ ) was similar to the results of our series (7\%). However, some publications report that hemorrhage risk is higher $(16 \%$ to $45 \%)$ in cases who develop fistulas $(1,4)$. Our mortality in these series was $8.5 \%$, whereas that in our patients with hemorrhage was $46 \%$.

A medical approach is preferred for the treatment of hemorrhages. In Grade A patients, a conservative approach is more frequently performed in the foreground, whereas in Grade B and $C$ patients, additional processes are required to identify the localization of the hemorrhage. Nasogastric tube (35\%), decrease in hemoglobin level (17\%), hemodynamic instability (15\%), blood coming out of the drains (11\%), and the presence of melena (9\%) may be helpful to make a diagnosis and determine the source of bleeding (8). Which can be determined by computerized tomography (CT) angiography in half of these cases (8). In cases where hemodynamic stability is preserved, first actions are monitoring the patient's hemodynamic levels and drains. Darnis et al. have stated that in their series of 285 cases with hemorrhage, the hemorrhages were stopped with a medical approach in 32\% of cases; yet in $68 \%$ of cases, intervention (surgical, endoscopic, or embolization) was needed $(8,9)$. In our series, CT angiography was performed in seven cases which revealed; hemorrhage from the portal vein in two cases, from the gastroduodenal artery in one case, and from the pancreatic artery in one case. The hemorrhage was stopped by embolization in one of these patients, and the rest underwent surgery. In a Grade A patient in our series, the hemorrhage stopped after conservative treatment and cessation of $\mathrm{LMWH}$.

Hemorrhages into the lumen are seen in earlier periods. The most common type is hemorrhage arising from pancreaticojejunal anastomosis. In hemorrhages arising from gastrojejunal anastomosis, both diagnostic and therapeutic procedures may be performed by endoscopists. In a series by Eckardt et al., the authors have stated that the source of bleeding may be detected and treated endoscopically in one third of hemorrhages arising from gastrojejunostomy (10). Variable approaches are used for this purpose, such as injection, sclerotherapy, and clip application.

It is expressed that the routine use of somatostatin analogs in the postoperative period to both suppress pancreatic secretion and prevent complications due to fistula, particularly bleeding in cases where fistulas have developed, reduces morbidity; however, these analogs have no positive effects on mortality (11). However, in some cases, protective effects have been reported (3). It was found in our series that the risk of hemorrhage was higher (13\%) in patients who developed fistulas. We also use somatostatin analogs routinely in our patients with fistulas. Soft pancreatic texture, thinness of the pancreatic duct, and the presence of fistulas are defined as major risk factors for hemorrhage (8). Tani et al. have defined the male gender, prolonged surgery, 
and blood transfusion as independent risk factors (12). Some studies report that parameters such as prolonged hospital stay, ERCP and stenting, the presence of preoperative jaundice, trau$\mathrm{ma} /$ resection of the splenic vessels, additional surgical procedures, older age, the presence of intraabdominal infection, and nutritional risk index are factors that increase the risk of hemorrhage $(2,7-9,12-14)$. Most of the factors mentioned above were present in our series (Table 1). It is to our belief that even though ERCP and stenting provide an advantage in reducing the bilirubin levels of the patient, it may cause new problems, such as technical difficulties and increasing the risk of infection by reducing the diameters of the ducts. It was detected that the duct was thin and the texture of the pancreas tissue was soft in cases with continued pancreatic secretion from the duct, whereas the duct was wide and the texture of the pancreas tissue was hard in cases in which the duct of Wirsung was invaded by the tumor.

Elevated CRP levels in the early postoperative period is an expected condition; however, continued elevation on the postoperative third day may be a precursor of fistulas and additional complications. In our series, the continuation of elevated CRP levels was evaluated as a precursor of fistula rather than hemorrhage. In the clinical study by Ansorge et al., it has been stated that elevated CRP levels may be an important precursor of fistula development $(15,16)$.

In cases with hemorrhage, the first preferred methods for locating the hemorrhage site are contrast-enhanced CT, CT angiog- raphy, and interventional angiographic embolization (Figure 1). The hemorrhage site can be localized by contrast-enhanced CT in half of these cases (8). It is shown in studies that the most important causes are hemorrhages arising from the stump of the gastroduodenal artery or pancreatic vessels and rupture or erosion of pseudoaneurysms of the splenic vessels. It is stated that hemorrhages can be stopped in $50 \%$ to $80 \%$ of cases who undergo embolization $(1,8)$. Darnis et al. recommend performing routine splenic artery embolization in cases with hemorrhage who undergo pancreaticoenteric anastomosis (8). Roulin et al. state that angiography and embolization can be performed easily in all vessels except for the hepatic artery and mesenteric artery and that these procedures are at least as effective as surgery (1). In our series, foci of hemorrhages that arose from the portal vein (three patients), gastroduodenal artery (two patients), pancreatic artery, and mesenteric veins were detected in six of the Grade $B$ and $C$ cases. Hemorrhage from the gastroduodenal artery was successfully stopped by inserting an angiographic coil in only one of these cases. In three of the 13 patients who underwent angiography, the bleeding site could be localized. However, in two of these patients, interventional coiling was not feasible due to the direct vicinity of the bleeding source to the portal vein. These methods were performed during the day because our hospital does not have 24-hour availability of endoscopists and interventional radiologists.

Some studies suggest covering the mesenteric artery/vein and the stumps of the cut splanchnic vessels with omental or fal-

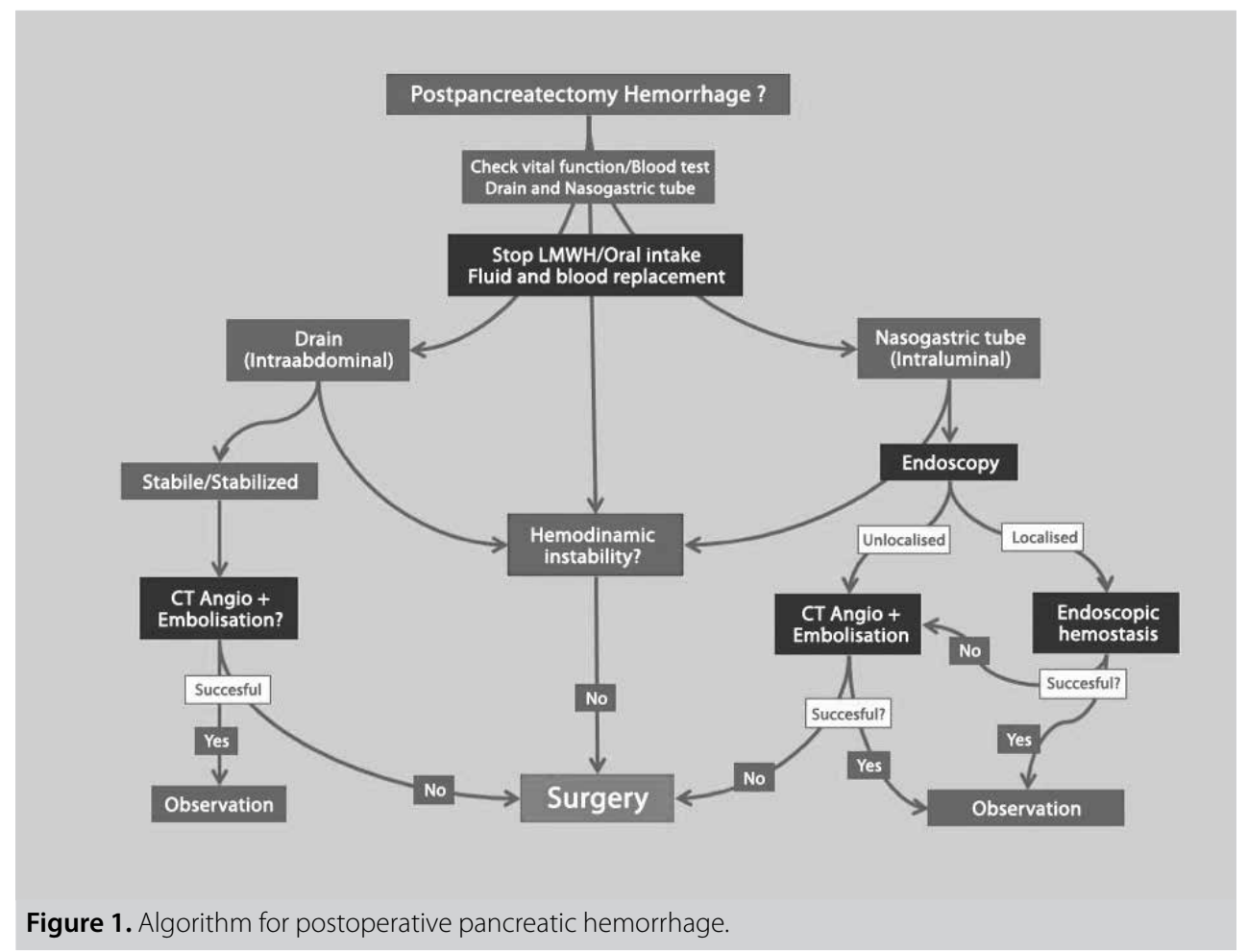


ciform flaps to prevent hemorrhage (17-19). In a clinical study performed in Japan, it has been stated that the risk of aneurysm development due to erosion is four times higher in patients without omental flap applications and that flaps are effective in preventing the formation of aneurysms (17). However, in the literature, in a series with low numbers of cases, the use of omental flap is described as a protective and useful procedure, whereas in meta-analyses and Cochrane studies, the use of omental flap is not described as useful $(12,20,21)$.

It is stated that hemorrhages arising from the cut pancreatic surfaces are important in etiology (22). Binding the vascular structures in pairs, using vessel sealers, and performing omental patches are suggested methods to prevent hemorrhages arising from pancreatic vessels. Adherence to the rules of surgical technique and hemostasis plays an important role in preventing hemorrhages in the early period $(14,23,24)$. Surgery remains the only option in conditions when conservative approaches, radiologic intervention, and endoscopic procedures are insufficient (Figure 1). Surgical treatment is performed in 30\% to $49 \%$ of the hemorrhages seen in patients with pancreaticoduodenectomy $(1,23,25,26)$. In our series, this rate was found to be $77 \%$ due to lack of 24 -hour availability of endoscopy and interventional radiology.

\section{CONCLUSION}

In addition to known methods, angiography and embolization have emerged as effective and promising methods in the diagnosis and treatment of hemorrhage. Furthermore, determination and elimination of independent risk factors, such as jaundice which affect fistula formation and bleeding in the perioperative period, is important for prevention.

Informed Consent: Written informed consent was obtained from all the patients who participated in this study.

Peer-review: Externally peer-reviewed.

Author Contributions: Concept - O.N.D.; Design - O.N.D.; Supervision - O.N.D.; Resource - O.Ö., N.C., T.A.; Materials - O.Ö., N.C., T.A.; Data Collection and/or Processing - E.Ö.G., M.H., S.C.Ç.; Analysis and/or Interpretation - O.N.D., E.Ö.G.; Literature Search - M.H., O.N.D.; Writing Manuscript - O.N.D.; Critical Reviews - O.N.D., M.H.

Conflict of Interest: No conflict of interest was declared by the authors.

Financial Disclosure: The authors declared that this study has received no financial support.

\section{REFERENCES}

1. Roulin D, Cerantola Y, Demartines N, Schäfer M. Systematic review of delayed postoperative hemorrhage after pancreatic resection. J Gastrointest Surg 2011; 15: 1055-62. [CrossRef]

2. Yekebas EF, Wolfram L, Cateldegirmen G, Habermann CR, Bogoevski $D$, Koenig AM, et al. Postpancreatectomy hemorrhage; diagnosis and treatment. An analysis in 1669 consecutive pancreatic resections. Ann Surg 2007; 246: 269-80. [CrossRef]
3. Gurusamy KS, Koti R, Fusai G, Davidson BR. Somatostatin analogues for pancreatic surgery. Cochrane Database Syst Rev 2012; 13: 6:CD008370

4. Bassi C, Dervenis C, Butturini G, Fingerhut A, Yeo C, Izbicki J, et al. Postoperative pancreatic fistula: An international study group (ISGPF) definition. Surgery 2005; 138: 8-13. [CrossRef]

5. Wente MN, Veit JA, Bassi C, Dervenis C, Fingerhut A, Gouma DJ, et al. Postpancreatectomy hemorrhage (PPH): an International Study Group of Pancreatic Surgery (ISGPS) definition. Surgery 2007; 142: 20-5. [CrossRef]

6. Grützman R, Rückert F, Hippe-Davies N, Distler M, Saeger HD. Evaluation of the international study group of pancreatic surgery definition of post-pancreatectomy hemorrhage in a high volüme center. Surgery 2012; 151:612-20. [CrossRef]

7. Balachandran P, Sikora S, Raghavendra RV, Kumar A, Saxena R, Kappor VK. Haemorrhagic complications of pancreaticoduodecnectomy. ANZ J Surg 2004; 74: 945-50. [CrossRef]

8. Darnis B, Lebeau R, Chopin-Laly X, Adham M. Postpancreatectomy hemorrhage (PPH): predictors and management from a prospective database. Langenbecks Arch Surg 2013; 398: 441-8. [CrossRef]

9. de Castro S, Kuhlmann KFD, Busch ORC, Van Delden OM, Lameris JS, Van GulikTM, et all. Delayed massive hemorrhage after pancreatic and biliary surgery: embolization or surgery? Ann Surg 2005; 241: 85-91.

10. Eckardt AJ, Klein F, Adler A, Veltzke-Schlieker W, Warnick P, Bahra M, et al. Management and outcomes of haemorrhage after pancreatogastrostomy versus pancreatojejunostomy. Br J Surg 2011; 98: 1599-607. [CrossRef]

11. Jin K, Zhou H, Zhang J, Wang W, Sun Y, Ruan C, et al. Systematic review and meta-analysis of somatostatin analogues in the prevention of postoperative complication after pancreaticoduodenectomy. Dig Surg 2015; 32: 196-207. [CrossRef]

12. Tani M, Kawai M, Hirono S, Hatori T, Imaizunmi T, Nakao A, et al. Use of omentum or falciform ligament does not decrease complications after pancreaticoduodenectomy: Nationwide survey of the Japanese Society of Pancreatic Surgery. Surgery 2012; 151: 183-91. [CrossRef]

13. Muscari F, Suc B, Kirzin S, Hay JM, Fountainer G, Fingerhut A, et al. Risk factors for mortality and intraabdominal complications after pancreatoduodenectomy: multivariate analysis in 300 patients. Surgery 2005; 139: 591-8. [CrossRef]

14. Adam U, Makowiec F, Riediger H, Schareck WD, Benz S, Hopt UT. Risk factors for complications after pancreatic head resection. Am J Surg 2004; 187: 201-8. [CrossRef]

15. Ansorge C, Nordin JZ, Lundell L, Strommer L, Rangelova E, Blomberg $J$, et al. Diagnostic value of abdominal drainage in individual risk assessment of pancreatic fistula following pancreaticoduodenectomy. BJS 2014; 101: 100-8. [CrossRef]

16. Palani Velu LK, McKay CJ, Carter CR, McMillan DC, Jamieson NB, Dickson EJ. Serum amylase and C-reactive protein in risk stratification of pancreas-specific complications after pancreaticoduodenectomy. $\mathrm{Br}$ J Surg 2016; 103: 553-63. [CrossRef]

17. Matsuda H, Sadamori H, Umeda Y, Shinoura S, Yoshida R, Satoh D, et al. Preventive effect of omental flap in pancreaticoduodenectomy against postoperative pseudoaneurysm formation. Hepatogastroenterology 2012; 59: 578-83. [CrossRef]

18. Maeda A, Ebata T, Kanemoto H, Matsunaga K, Bando E, Yamaguchi $S$, et al. Omental flap in pancreaticoduodenectomy for protection of splanchnic vessels. World J Surg 2005; 29: 1122-6. [CrossRef]

19. Abe N, Sugiyama M, Suzuki Y, Yanagida O, Masaki T, Mori T, et al. Falciform ligament in pancreatoduodenectomy for protection of skeletonized and divided vessels. J Hepatobiliary Pancreat Surg 2009; 16: 184-8. [CrossRef] 
20. Tian Y, Ma H, Peng Y, Li G, Yang H. Preventive effect of omental flap in pancreaticoduodenectomy against postoperative complications: a meta-analysis. Hepatogastroenterology 2015; 62: 187-9.

21. Tien YW, Lee PH, Yang CY, Ho MC, Chiu YF. Risk factors of massive bleeding related to pancreatic leak after pancreaticoduodenectomy. J Am Coll Surg 2005; 201: 554-9. [CrossRef]

22. Ramia JM, de la Plaza R, Adel F, Ramiro C, Arteaga V, Garcia-Parreo J. Wrapping in pancreatic surgery: a systematic review. ANZ J Surg 2014; 84: 921-4. [CrossRef]

23. Turrini O, Delpero JR. Omental flap for vessel coverage during pancreaticoduodenectomy: a modified technique (Article in French with english abstract). J Chir (Paris) 2009; 146: 545-8. [CrossRef]
24. Braga M, Capretti G, Pecorelli N, Balzano G, Doglioni C, Ariotti R, et al. A prognostic score to predict major complications after pancreaticoduodenectomy. Ann Surg 2011;254: 707-8. [CrossRef]

25. Balcom JHIV, Rattner DW, Warshaw AL, Chang Y, Fernandez-del Castillo C. Ten-year experience with 733 pancreatic resections. Arch Surg 2001; 136: 391-8. [CrossRef]

26. Choi SH, Moon HJ, Heo JS, Joh JW, Kim YI. Delayed hemorrhage after pancreaticoduodenectomy. J Am Coll Surg 2004; 199: 186-91. [CrossRef]

\section{OLGU SERISI-ÖZET}

Turk J Surg 2019; 35 (2): 136-141

\section{Whipple ameliyatı sonrasında karşılaşılan kanama problemi}

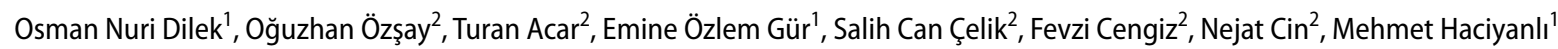

1 İzmir Katip Çelebi Üniversitesi Tıp Fakültesi, Genel Cerrahi Anabilim Dalı, İzmir, Türkiye

${ }^{2}$ Atatürk Eğitim ve Araştırma Hastanesi, Genel Cerrahi Kliniği, İzmir, Türkiye

\section{ÖZET}

Giriş ve Amaç: Whipple ameliyatları, halen vazgeçilmez bir ameliyat tekniği olmasının yanında, yüksek morbiditesi (\%30-60) ve mortalitesi (\%5) ile cerrahinin çözüm bekleyen önemli sorunlarından biri olmaya devam etmektedir. Postoperatif hemoraji ise literatürde \%5-16 sıklıkta görülmektedir. Bu çalışmada ameliyat sonrası karşılaşılan kanama problemleriyle ilgili olarak kliniğimiz verileri ve sonuçları irdelenmiştir.

Gereç ve Yöntem: Son beş yılda, hastanemizde Whipple ameliyatı yapılan 185 hastamızın dosyaları retrospektif olarak değerlendirilerek kanama nedenleri ortaya konulmaya çalışılmıştır.

Bulgular: Toplam 13 (\%) hastada kanama nedeniyle işlem yapıldığı, bunlardan altısının eksitus olduğu saptandı. Olgulardan altısında fistüle bağıı olarak değişen süreler içerisinde portal ven, gastroduodenal arter ve pankreas arterlerinden kanadığı saptandı. Sepsis sonucu iki olguda dissemine intravasküler koagülasyona bağlı kanamaların geliştiği saptandı. İki olguda mezo venlerinden, bir olguda ise portal venden gelişen kanamaya erken dönemde müdahale edilmiştir. Mide anastomoz hattından kanama gelişen bir hastamızda laparotomi ve hemostaz yapıldı. Profilaktik düşük molekül ağırlıklı heparin verilmekte olan bir hastamızda dren ve nazogastrik sondalardan olan kanamanın ilacın kesilmesini takiben durduğu saptandı.

Sonuç: Whipple ameliyatı sonrasında görülen kanamaların durdurulması amacıyla çeşitli koruyucu işlemler uygulanmaktadır. Sonuç olarak, bilinen yöntemlerin yanında, anjiyografi ve embolizasyon kanamaların tanı ve tedavisinde oldukça etkili bir yöntem olarak ortaya çıkmaktadır. Ayrıca, kanama ve fistül oluşumuna etkili sarılık gibi bağımsız risk faktörlerinin peroperatif dönemde belirlenmesi ve giderilmesi korunma için önemlidir.

Anahtar Kelimeler: Komplikasyon, kanama, pankreas, tedavi, whipple ameliyatı

Doi: $10.5578 /$ turkjsurg.3758 